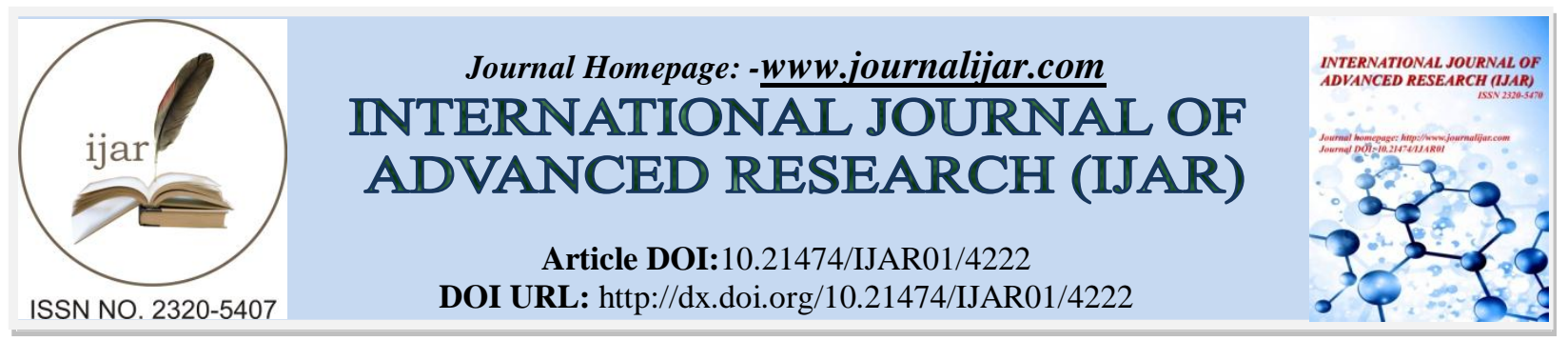

RESEARCH ARTICLE

\title{
MOLECULAR IDENTIFICATION EFFECT OF WASTEWATER ON PLANT AND BACTERIAL DNA.
}

\section{Hanan H. Ahmed ${ }^{1}$ and Osama M. Abonama ${ }^{2}$.}

1. Department Of Microbial Biotechnology, Genetic Engineering and Biotechnology Research Institute, University of Sadat City

2. Department of Industrial Biotechnology, , Genetic Engineering and Biotechnology Research Institute, University of Sadat City, Egypt

\section{Manuscript Info}

Manuscript History

Received: 18 March 2017

Final Accepted: 21 April 2017

Published: May 2017

\section{Abstract}

In this research, the effect of effluent was investigated in the DNA of Vicia faba plant and Rhizobium leguminosarum bacterial isolate. In this study, sterilized treated effluent was used to irrigate seeds of Vicia faba for 45 days. The results by Gel electrophoresis and Fluorescence Spectrometer suggested that the wastewater has damage effect on DNA in Vicia faba and Rhizobium leguminosarum, possibly due to the effect of mutagenicity and toxicity of heavy metals of effluent compared with control (plant and bacteria irrigated with tap water) and it has hazardous effect on microorganisms, animals, human health and environment.

Copy Right, IJAR, 2017,. All rights reserved.

\section{Introduction:-}

Wastewater contains nutrients which can stimulate the growth of marine plants.

It may also contain toxic compounds that are potentially considered mutagenic or carcinogenic. Microbiological and biochemical techniques such as RNA and DNA typing are being used to identify the active mass in biological treatment of wastewater sample (George et al. 2003).

This was extend to test the harm occurred to DNA molecules of effectual microbes (EMs) by heavy metal ions As ${ }^{3+}$, $\mathrm{Cd}^{2+}, \mathrm{Cr}^{3+}, \mathrm{Cu}^{2+}, \mathrm{Hg}^{2+}, \mathrm{Pb}^{2+}$ and $\mathrm{Zn}^{2+}$, as well as the effects of EM on wastewater treatment when their DNA damaged were recorded. It was also focused on investigating the damage of (EM) DNA in wastewater with diverse concentrations of heavy metal ions $\mathrm{As}^{3+}, \mathrm{Cd}^{2+}, \mathrm{Cr}^{3+}, \mathrm{Cu}^{2+}, \mathrm{Hg}^{2+}, \mathrm{Pb}^{2+}$ and $\mathrm{Zn}^{2+}$, and the effect of these heavy metals on COD degrading ability in wastewater was also studied. (Zhou et al. 2008).

Similar studies investigated cytotoxic, mutagenic and genotoxic special effects of diverse concentrations of wastewater as the phosphoric gypsum store near the factory of fertilizing agents. The ames analysis was performed on Salmonella typhimurium TA98 and TA100 strains. In the existence of S9 mix, glutathione and solution respectively, no mutagenic effects of phosphoric gypsum on Salmonella typhimurium strains in the presence of S9 mix, GSH or PBS were observed. On the other hand, strong cytotoxic effect was observed on both human cell lines when they were treated with diverse concentrations of wastewater. The harm was not repaired, but increased through the time of incubation. The results of the alkaline comet assay show considerable possible DNA damaging effect of wastewater on human leukocytes. Since phosphoric gypsum move water in its present composition and acidity is highly toxic and acts as pro-oxidant, causing free radicals creation and DNA damage. This requires cleansing by 
urgent neutralization of wastewater to a level that is suitable for disposal into the environment (Durgo et al.2009). The obtained effect was a result of both (single- and double-strand DNA breaks) and roundabout effects (oxidative damage) caused through the united effects of all contaminants found in the tested water samples. (Zlatko et al.2011).

Samples of River Damodar were tested, microbes and chemical waste unnecessary in the river. The objective was to study the damage occurring in DNA is synthesized by industrial wastewater. In steel and iron industries, a large number of industrial wastewater pollutants were detected display a strong mutagenic effect. Wastewater on the DNA synthesis anda difference in the optical density of the acid (DNA) was observed, which could possibly be due to the aromatic toxic heavy metals and phenolic compounds found in the water. (Aamir et al .2013).

Common effluent treatment plant (CETP) use to reduce the genotoxicity from the raw effluent. In this study, authors investigated the genotoxic effects of the tannery effluent in mung bean. The Untreated and treated tannery of CETP were collected (UP), India, were grown mung bean seeds in the soil irrigated for 15 days with different concentrations of tannery effluents $(0.25,50.75,100 \%)$. The inhibition of seed germination $90 \%$ of the untreated effluent of $25 \%$ and $75 \%$ of treated water, compared to the Control Plants. Plant growth was $51 \%$ and $41 \%$ when irrigated with untreated effluent or treated at a concentration of $25 \%$ compared with the control plants. This shows that the treated effluent is less genotoxic than without treatment. Similarly Nei's genetic indicators calculated between treatments and control plants showed the plants irrigated with tannery effluent had a similarity index of 0.75 , control plants and plants irrigated with untreated is 0.65 , and 0.68 between treatments. It was and concludethat each of untreated sewage or treated contains genotoxic substances that cause DNA damage to the beans. CETP removes some, but not all, of genotoxic substances from the tannery effluent (Abhay et al. 2014).

This research aims to study the effect of effluent in DNA of Vicia faba plant as eukaryote and Rhizobium leguminosarum bacterial isolates as prokaryote, and the effect of effluent in DNA of Vicia faba plant and Rhizobium leguminosarum when treated alone and together with sterilized effluent compared with control (tap water). For this purpose, treated effluent is used to irrigate seeds of Vicia faba for 45 days.

\section{Materials and Methods;-}

\section{Bacterial Samples:-}

This includes bacteria used in this study: isolate of Rhizobium leguminosarum bacteria was grown in Yeast extract Mannitol Broth (YEMB) with treated effluent and with tap water as control. The same bacterial isolate used to inoculate Vicia faba seeds, and five isolates colonies from (each treat) root nodules of Vicia faba plant used in this study were isolated.

\section{Isolation of Bacteria from Root Nodules of Vicia Faba:-}

Five root nodules from plants were carefully excised from the roots of Vicia Faba irrigated with sterilized treated effluent and tap water and washed several times with sterilized water from adherent soil nodules. They were surfacesterilized by $0.1 \% \mathrm{HgCl}_{2}$ solution for 4 to 5 minutes and treated with ethyl alcohol (95\%) for 3 minutes. Nodules were washed several times with sterile distilled water. The surface sterilized nodules of each plant were crushed in $500 \mu 1$ of sterilized distilled water in a sterile Petri-dish. One loopful of the nodule suspension was streaked on yeast extract Mannitol agar (YEMA) containing Congo Red (three plates) for each. Well isolated colonies, characteristic of Rhizobiumthe colonies with a diameter ranging from 1-5 mm were picked up with circular entire or smooth margins, flexible, shiny and raised, which shows production of gumy, after 2 days in YEMA at $28^{\circ} \mathrm{C}$.

Gram stain and test the mobility testing, the studied isolate colonies were gram-negative, rod-shaped singly or in pairs, motile and changed the YEMA- BTB to yellow, the isolate colonies were bacteria produce acid. A positive oxidase test will result in a change color from violet to purple, All isolate colonies were catalase and oxidase positive., confirmed from the bubbling of oxygen around the bacterial colonies and a change in color appearance oxidase strip of deep purple color, were restreaked on YEMA plate Colonies were restreaked on YEMA plate many times to obtain pure isolates and the colonies that developed were used to inoculate YEMA slants, maintained on YEMA.

\section{Media:-}

Yeast extract Mannitol Broth (YEMB), Yeast Mannitol Agar (YEMA) and YEMA containing Congo Red (Somasegaran and Hoben, 1985) 


\title{
Determination of purity and identification of bacterial isolates:- Morphological Characteristics of Isolates Cultures:- \\ a. Isolate colonies morphological characteristics were identified as described by Lupwayi and Haque (1994). \\ b. Gram Stain,
}

\author{
Biochemical and Physiological Characteristics:- \\ Acid-base production (Jordan, 1984). \\ TestA oxidase and Catalase testA(Benson, 1994).
}

\section{Plant Growth and Conditions:-}

Vicia faba seeds were inoculated by Rhizobium leguminosarum bacteria after surface sterilization with $0.1 \% \mathrm{HgCl}_{2}$ for $5 \mathrm{~min}$. washed twice by distilled water. Sterilized treated effluent used to irrigate seeds of Vicia faba for 45 days. The plant seeds irrigated with tap water used as control. Each treatment was triple pots with 4 seeds for each.

\section{Bacterial DNA Extraction:-}

Procedures of bacterial DNA extraction from bacteria isolated from plant nodules were according to DNA extraction mini kit Intron Biotechnology Cat. No (17361)

\section{Plant DNA Extraction:-}

Nuclear DNA extraction was performed to isolate DNA from the bean-treatment and non-treatment plants 45 days. It has been carried out according to the procedures shown by Dehestani and Kazemi (2007) with some modifications.

\section{Agarose Gel Electrophoresis:-}

The extracted DNA was electrophoresed in a $1 \%$ agarose gel for $30 \mathrm{~min}$. according to known standard procedures

\section{Fluorescence Spectrometer:-}

Fluorescence Spectrometer is used to detect DNA damage in various organisms. The fluorescence of Eth-B alone is less than 1/10 the Eth-B-DNA complex fluorescence. Various UV sources of fluorescent used to detect Eth-B-DNA complexes and solution of DNA with Eth-B was measured immediately. In this study Fluorescence Spectrometer used to measure DNA $(2 \mu \mathrm{l}$ from sample were with $2 \mathrm{ml}$ deionizedwater) in a quartz cuvette, and measured the same sample in the presence of $1 \mu \mathrm{l}(1 \mu \mathrm{g} / \mathrm{ml})$ of Ethidium Bromide measured directly at $300 \mathrm{~nm}$.

\section{Results and Discussion:-}

\section{Identification and Characterization of Bacterial Isolates:-}

Congo Red with YEMA media, the coloring of the isolate colonies were milky translucent (white) and circular in shape. The colonies with circular entire or smooth margins, flexible, shiny and raised, which shows production of gumy, and after 2 days in YEMA at $28^{\circ} \mathrm{C}$., with a diameter ranging from $1-5 \mathrm{~mm}$ were picked up.

Gram stain and test the mobility test, the studied isolate colonies were gram-negative, rod-shaped singly or in pairs, motile and changed the YEMA- BTB to yellow, the isolate colonies were bacteria produce acid. A positive oxidase test will result in a change color from violet to purple. All isolate colonies were catalase and oxidase positive., confirmed from the bubbling of oxygen around the bacterial colonies respectively. These observations were confirmed by (Somasegaran and Hoben, 1994), (Singh et al. 2008) and (Lupwayi and Haque 1994).

\section{Comparing genomic DNA of Rhizobium leguminosarum isolates by gel electrophoresis:-}

Genomic DNA of Rhizobium leguminosarum bacteria affected by treated effluent when grown on YEMA media with effluent and the bacterial isolate colonies isolated from nodules of Vicia faba plant irrigated with effluent compared with control (bacteria grown in YEMA media with tap water). Figure (1A) shows the effect of effluent on the DNA. The results showed damage of DNA of the treated bacteria grown alone on YEMA media with effluent compared with the bacterial isolate colonies isolated from nodules of Vicia faba plant irrigated with effluent compared with control, and the bacterial isolate colonies grown on YEMA media with effluent are more affected by effluent. Zhou et al. (2008) studied and tested the harm to DNA of effectual microbes (EMs) by heavy metal ions as well as the effects of EM microorganisms on wastewater treatment ability when their DNA was damaged. 


\section{The effect of effluent on the DNA of Vicia faba plant by gel electrophoresis:-}

The genomic DNA of Vicia faba plant inoculated by Rhizobium leguminosarum bacteria after surface sterilization irrigated by sterilized treated effluent, when grown on sterilized soil and the Vicia faba plant alone irrigated with sterilized effluent was compared with control (Vicia faba plant grown in sterilized soil with tap water). Figure (1B) shows damage of DNA of the treated Vicia faba plant compared to control. Vicia faba plant alone irrigated with sterilized effluent are more effected by effluent. Effluent had genotoxic substances causing different levels of genotoxic effects that caused DNA damage to mung beans plant compared to between control and treated plants. The DNA damage in mung bean plants is possibly due to toxic effect of heavy metals consequently, use of treated wastewater for irrigation poses health hazard to both human, microorganisms, animals and the environment (Abhay et al. 2014).

A study showed wastewater of great Swiss University hospital with the intention of primary DNA damage. Previously generated Ames and V79 chromosomal aberration data of the same samples in Umweltbundesamt Texte (74/95) were compared with the newly generated results. Neither the mutagenic effects detected by the Ames assay $(8 \%, n=25)$ nor the positive V79 results $(46 \% n=13)$ seemed to be caused by ciprofloxacin. Therefore, the Ames and V79 results suggest the presence of additional mutagens that are yet to be identified (Hartmann et al. 1999).

\section{Comparing genomic DNA of Rhizobium leguminosarum isolates by Fluorescence Spectrometer:-}

The DNA from bacteria grown in media with effluent water are more affected and damaged than control (tap water). The DNA in bacteria growing in effluent water are more affected and damaged than bacterial isolate colonies from nodules of Vicia faba plant irrigated with effluent watercompared with control (fig. 2) from 1 to 15 showed the effect of bacterial DNA.

\section{The effect of effluent on the DNA of Vicia faba plant by Fluorescence Spectrometer:-}

The DNA in Vicia fabaplant irrigated with effluent is more damaged than control plant (irrigated with tap water). The DNA in plant irrigated with effluent is more damaged than plant with bacteria irrigated with effluent (fig. 2) from 16 to 30 showed the effect of Vicia fabaplant DNA.

Symbiosis between plant and bacteria may be decreasing the harmful effect of effluent water on DNA compared with DNA of plant only treated with effluent and bacteria only treated with effluent.

In exploratory measurement fluorescence spectrum examined the DNA from $100 \mathrm{ppm}$ calf thymes (Hargiset al. 1995). In the same context, Sunita et al. (2008) mentioned that UV-A (315-400 nm) radiation is less efficient in inducing DNA damage because it is not absorbed by native DNA. The result of the sewage on DNA synthesis and the difference in the optical density of the DNA was also noted (Aamir et al. 2013).

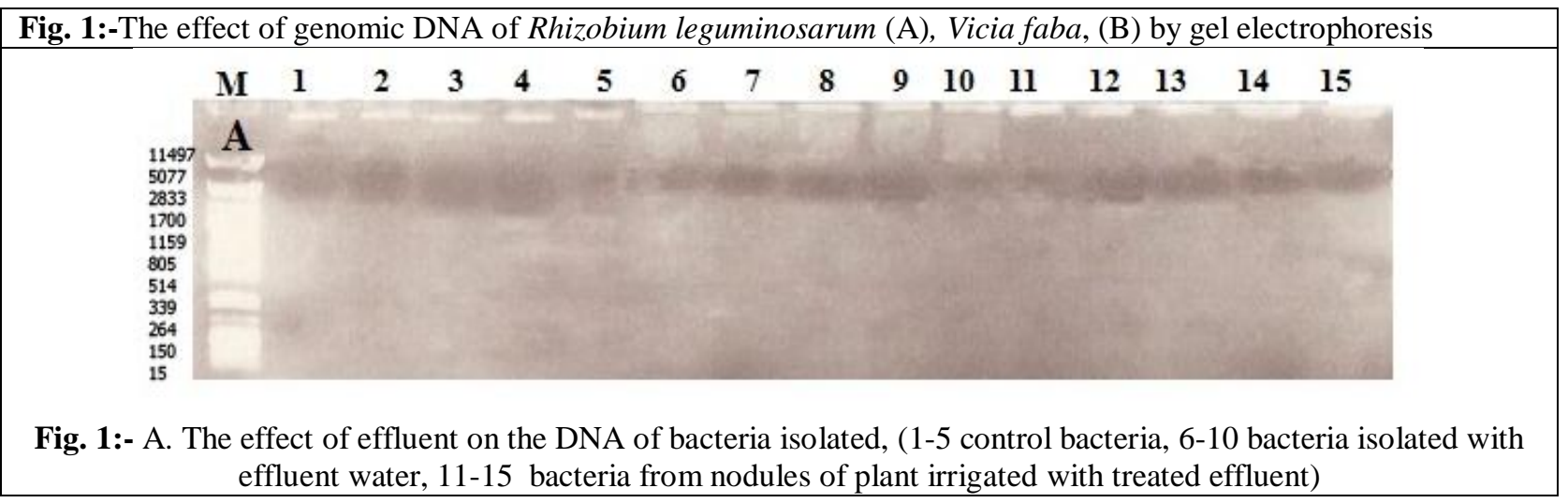




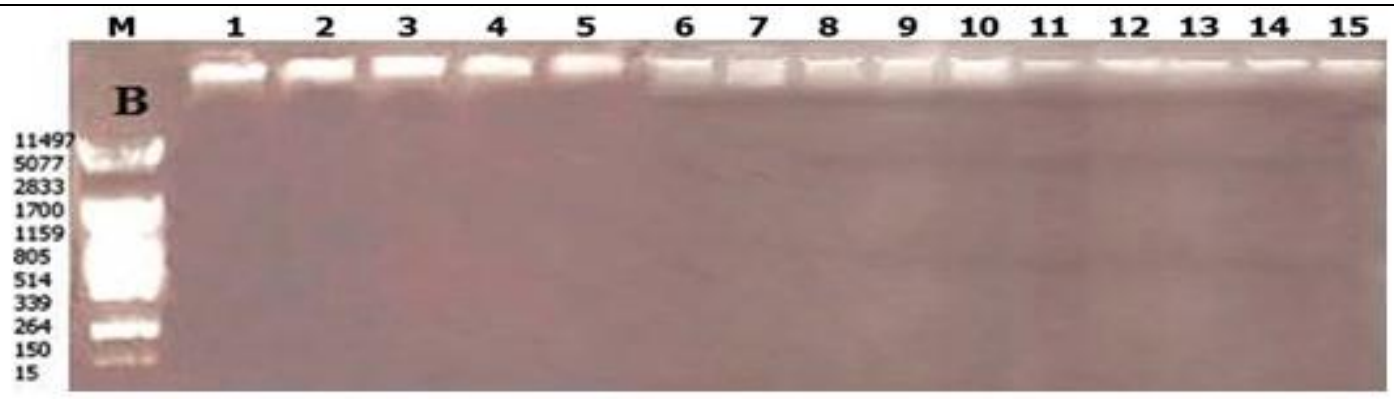

Fig.1:-B. The effect of effluent on the DNA of Vicia faba plant, (1-5 control plant, 6-10 plant irrigated with effluent water, 11-15 plant symbiosis with bacteria irrigated with effluent )

Fig. 2:- The effect of DNA on Rhizobium leguminosarum and Vicia faba determined by Fluorescence Spectrometer
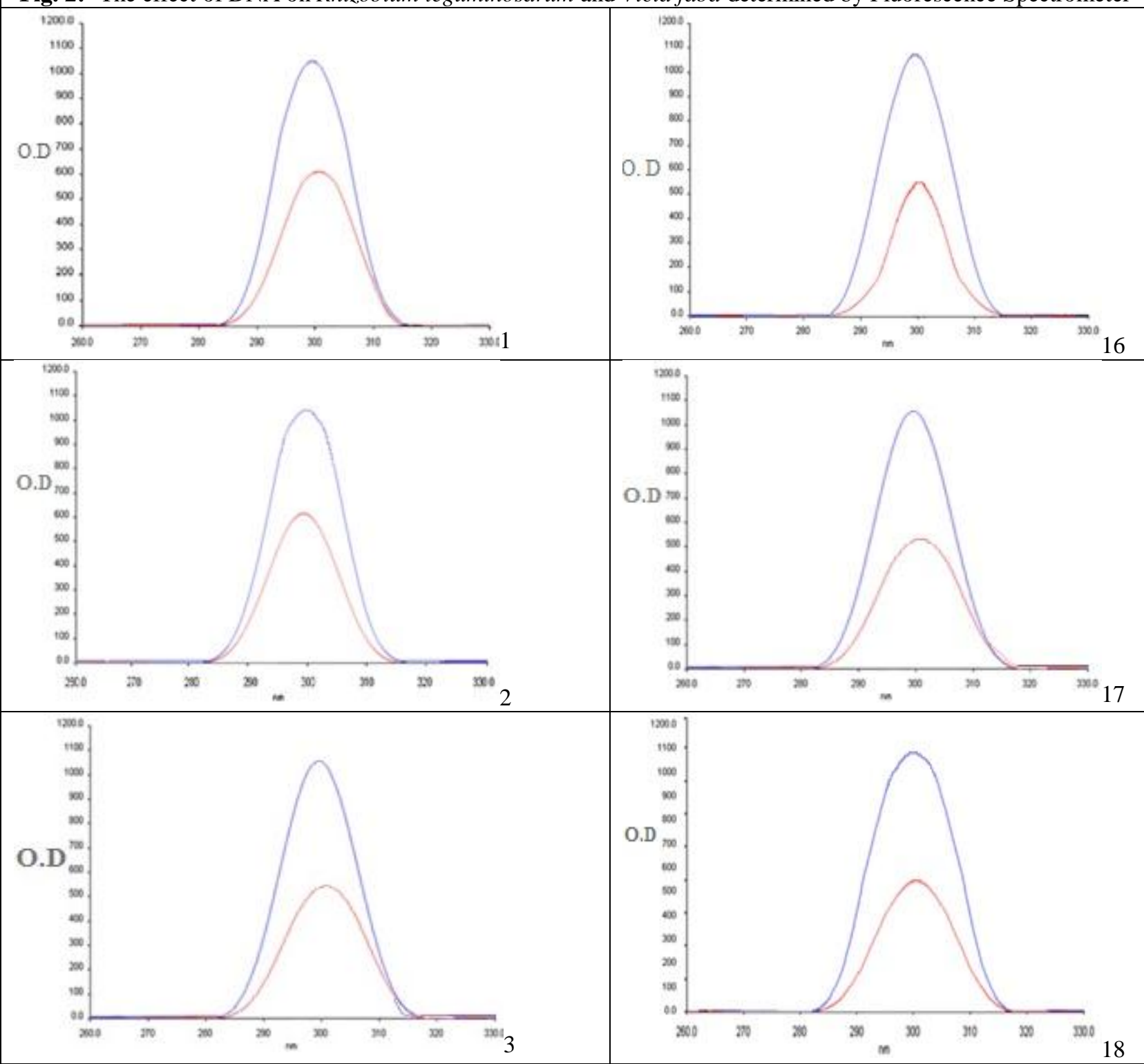
ISSN: 2320-5407

Int. I. Adv. Res. 5(5), 1113-1121

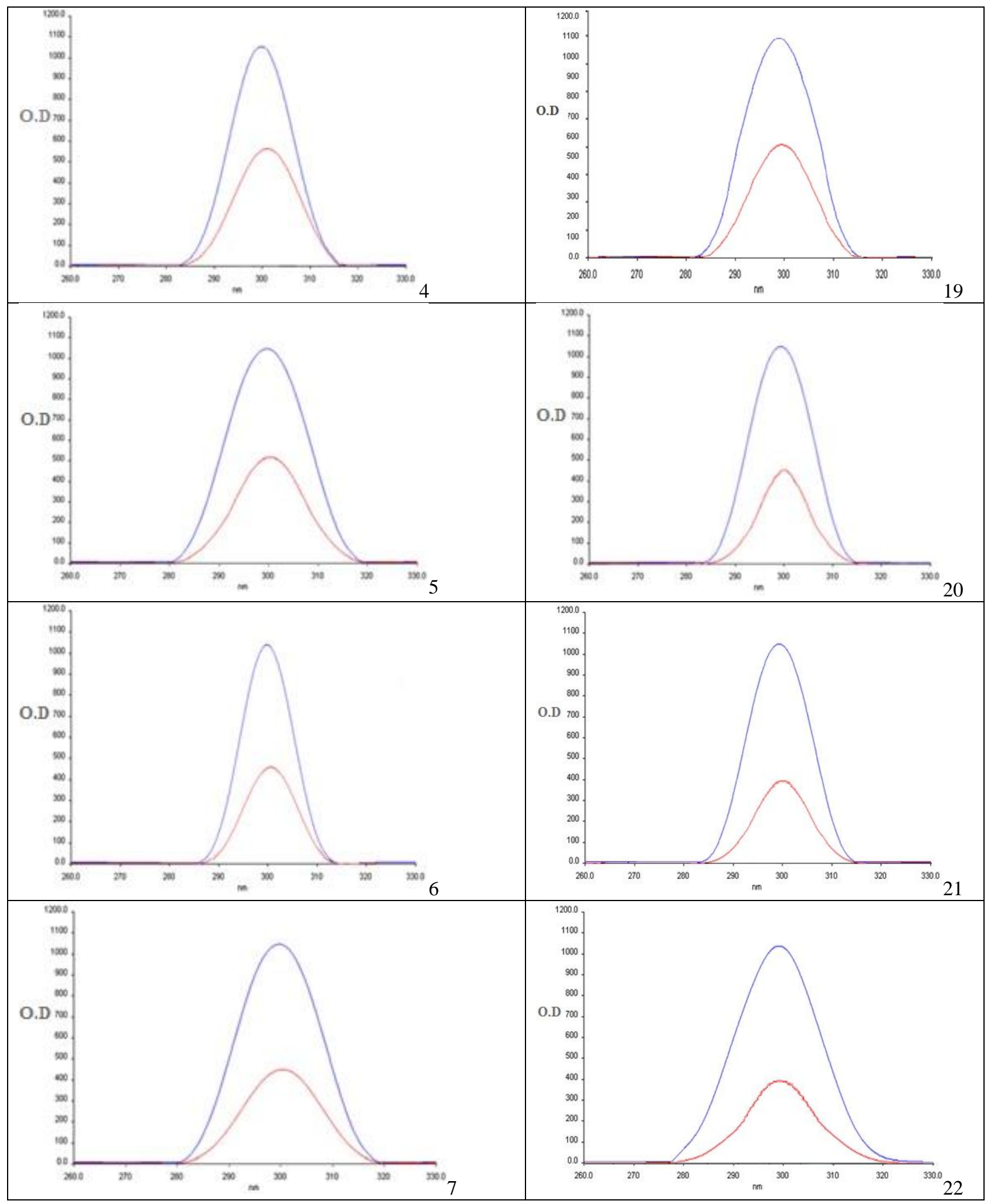

1118 
ISSN: 2320-5407

Int. J. Adv. Res. 5(5), 1113-1121

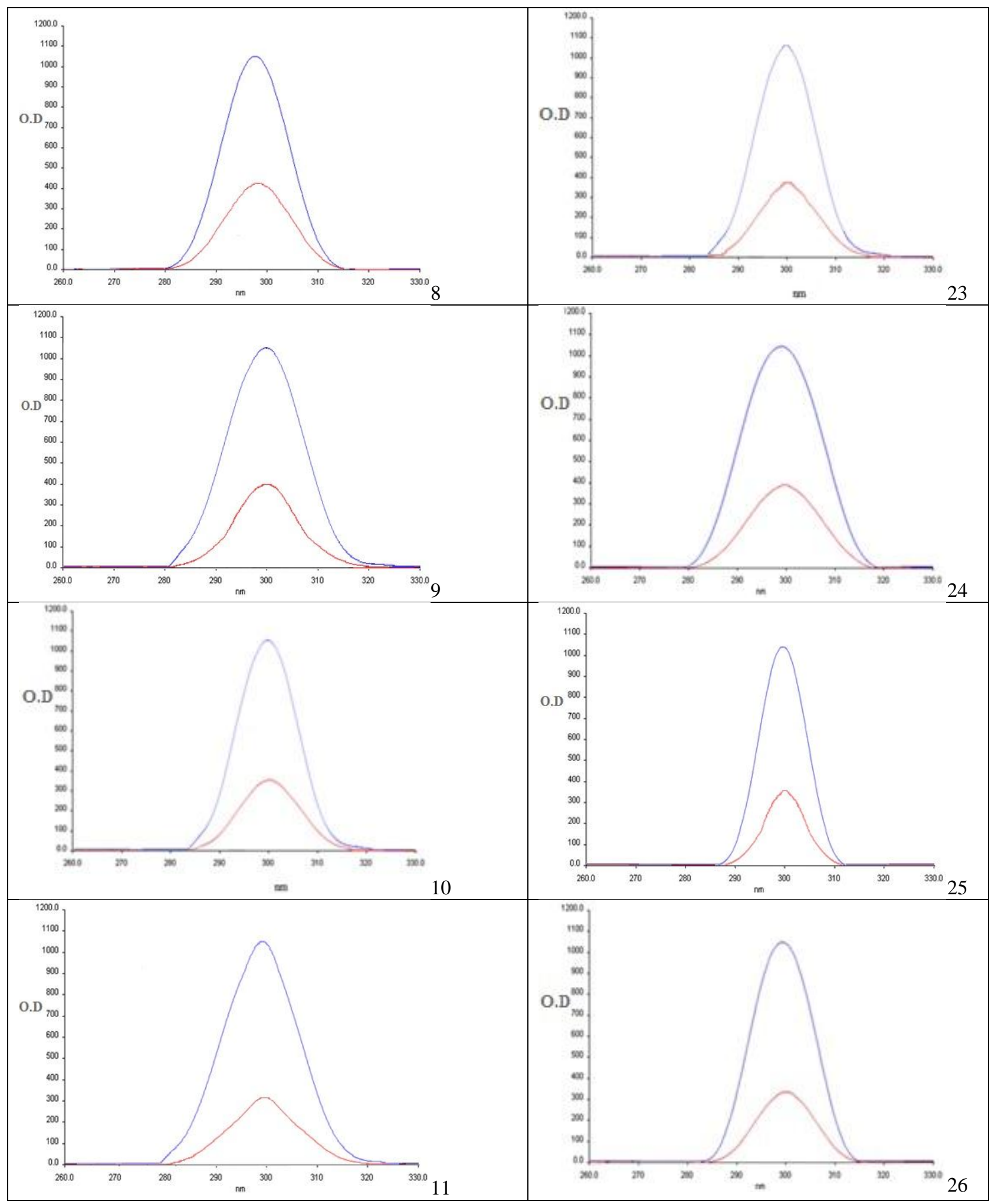

1119 

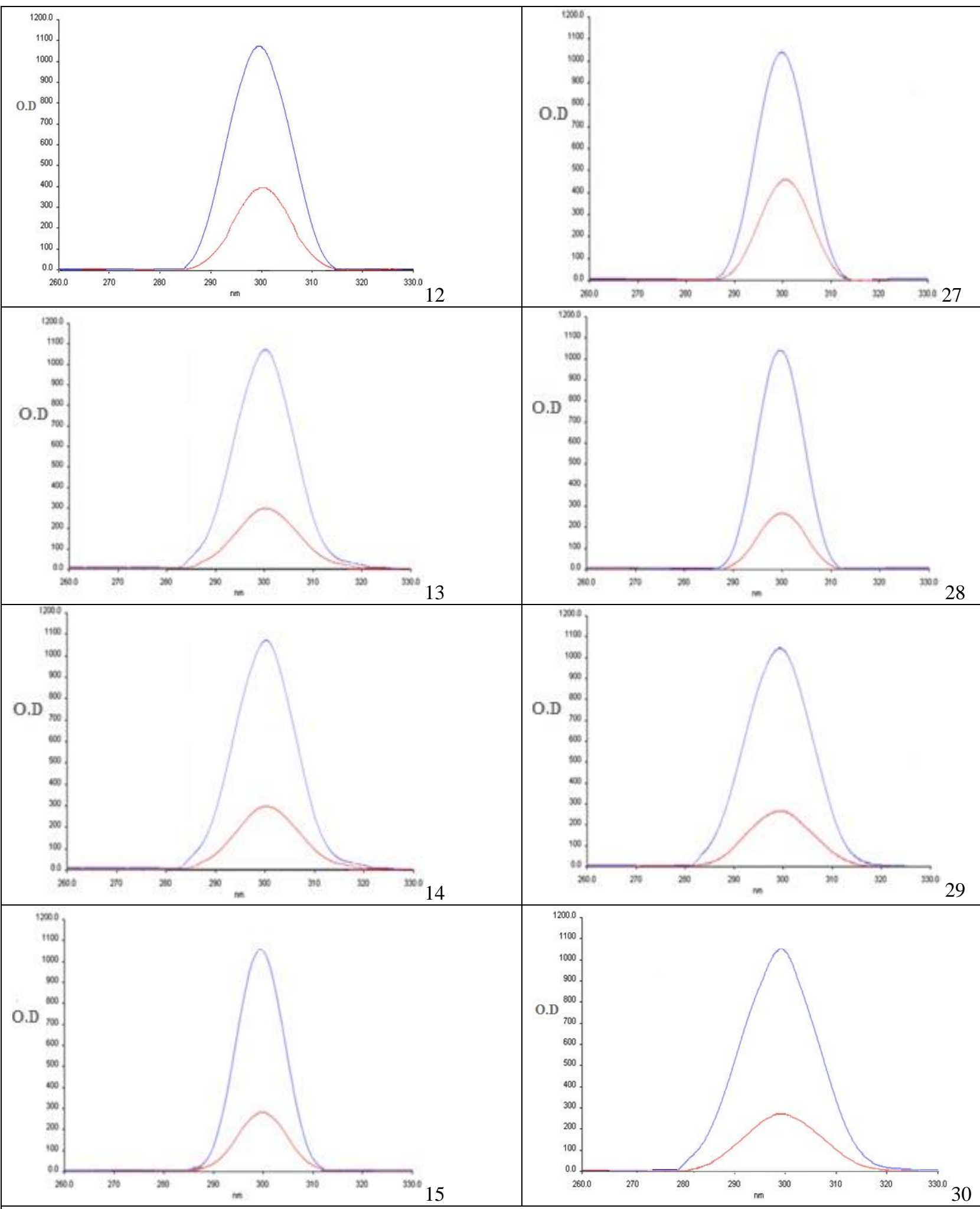

The Fluorescence Spectrometer peaks for DNA (blue line) and EthB-DNA (red line): 1-5 control bacteria, 6-10 bacteria isolated from nodules of plant irrigated with effluent water, 11-15 bacteria isolated grown in media with effluent water, 16-20 control plant, 21-25 plant irrigated with effluent water symbiosis with bacteria, 26-30 plant only irrigated with effluent water. 


\section{Conclusion:-}

Effect of effluent in DNA Vicia faba plant as eukaryote and Rhizobium leguminosarum bacterial isolates as prokaryote, The damage determined quality by gel electrophoresis and quantity by Fluorescence Spectrometer when treated alone were more than the effect of effluent in DNA of Vicia faba plant and Rhizobium leguminosarum when treated together with sterilized effluent (symbiosis between plant and bacteria may be decreasing the harmful effect of effluent water on DNA). In both Effect of effluent in Vicia faba plant DNA as eukaryote more than Rhizobium leguminosarum bacterial isolate DNA as prokaryote, compared with control (tap water).

\section{Referances:-}

1. Aamir J., Anup B., Ishwarya.M.S, Firoz A. and Hidayatullah Md. (2013). Bioremediation of industrial reffluents of asanso ID urgapur industril zone and its effect on DNA. G.J.B.B., 2 (2): 215-226 ISSN 2278 9103.

2. Abhay R.,Sharad K., Izharul H. and Mahadeo K. (2014). Detection of Tannery Effluents Induced DNA Damage in Mung Bean by Use of Random Amplified Polymorphic DNA Markers. ISRN Biotech., 1-8.

3. Benson, H. J. (1994): Microbiological Applications. 6th ed., Wm. C. Brown Pub., Dubuque, Iowa, Oxfor.

4. Dehestani A. and Kazemi S.K. (2007). A Rapid Efficient Method for DNA Isolation from Plants with High Levels of Secondary Metabolites. Asian J Plant Sci. 6 (6) : 977-981.

5. Durgo K., Orescanin V., Lulić S., Kopjar N., Eljezić DZ. And Colić JF. (2009). The Assessment of Genotoxic Effects of Wastewater From a Fertilizer Factory. J Appl Toxicol. Jan; 29 (1): 42-51.

6. George T., Franklin L. Burton, H. and David L. (2003).Wastewater Engineering Treatment and Reuse. (Fourth Edition).

7. Hargis P.J., Soboring T.J., Tisone G.C. and Wagner J.S. (1995). Ulraviolet Fluoresc Detection and Identification of Protein, DNA and Bacteria. SPIE: 2366. 147-153.

8. Hartmann A., Golet E. M., Gartiser S., Alder A. C., Koller T. and Widmer R. M. (1999). Primary DNA Damage But Not Mutagenicity Correlates with Ciprofloxacin Concentrations in German Hospital Wastewaters. Arch Environ ContamToxicol., 36 (2): 115-119.

9. Jordan, D.C. (1984). Family III. Rhizobiaceae. In: Bergeys Manual of Systematic Bacteriology, 234-254, (Krieg, N. R. and Holt, J. G. eds). The WilLong, S. R. (1989). Rhizobium Genetics. Annual Review of Genetics. 23: $483-506$

10. Lupwayi, N. and Haque, I. (1994). Legume-Rhizobium Technology Manual. Environmental Sciences Division International Livestock Center for Africa. Addis Ababa, Ethiopia. 1-93

11. Singh, B., Kaur, R.and Singh, K. (2008). Characterization of Rhizobium Strain Isolated From Trigonella foenumgraecum (Fenugreek). Africa. J. Biotech. 7:3671-3676.

12. Somasegaran P. and Hoben H. J. (1985). Methods in Legume Rhizobium Technology. IFTAL, Paia, Moui. HI, USA.

13. Sunita K., Rajesh P., Kanchan L., Singh, Shailendra P. and Rajeshwar P. (2008). DNA Damage: Detection Strategies.Excli J. 2008; 7: 44-62 - ISSN 1611-2156.

14. Somasegaran P., and Hoben Heinz J. (1994). Handbook for Rhizobia Methods in Legume-Rhizobium Technology. Springer - Verlag, New York. 1-441.

15. Zhou S., Wei C., Liao C. and Wu H. (2008). Damage to DNA of Effective Microorganisms by Heavy Metals: impact on wastewater treatment. J. Environ Sci (China). 20(12): 1514-518.

16. Zlatko M. , Ivanc`ica T., Igor S. k.,c', Marija I.,' Davor Z.,', Marin M., and Nevenka K. (2011). Assessment of Genotoxic Potency of Sulfate-Rich Surface Waters on Medicinal Leech and Human Leukocytes Using Different Versions of The Comet Assay. Ecotoxicol and Environ Saf., 74 : 1416-1426. 